\title{
Analisis Balanced Scorecard Sebagai Pendekatan Penilaian Kinerja Pada Koperasi Kartika Sultan Ageng Tirtayasa Serang
}

\author{
Ihwan Satria Lesmana \\ Universitas Bina Bangsa Banten \\ ihwansatrialesmana@gmail.com
}

\begin{abstract}
Abstrak
Koperasi merupakan salah satu pelaksana pembangunan perekonomian di Indonesia yang diharapkan mampu meningkatkan kinerjanya agar dapat berjalan sejajar dan berdampingan dengan sektor pemerintah dan sektor swasta dalam memajukan perekonomian nasional. Agar dapat terlaksananya harapan tersebut diperlukan adanya pengukuran kinerja yang dapat digunakan untuk menilai keberhasilan, mengevaluasi hasil kerja, dan mendeteksi kelemahan atau kekurangan yang masih ada dalam Organisasi. Sesuai dengan tujuan penelitian, metode yang digunakan adalah deskriptif kualitatif. Dalam penerapan penggunaan balanced scorecard pada koperasi, maka ada penyesuaian pada empat perspektif dalam balanced scorecard, yaitu: perspektif keuangan, perspektif pelanggan, perspekif bisnis internal, dan perspektif pembelajaran dan pertumbuhan. Dalam penelitian ini dilakukannya studi kasus dengan penentuan sampel menggunakan random sampling yang dihitung dengan rumus slovin. Sumber data yang digunakan adalah informan, dokumen dan arsip. Teknik pengumpulan data yang digunakan adalah wawancara, observasi, dan analisis dokumen. Hasil empat perspektif yang ada pada metode balanced scorecard, yaitu bagian perspektif keuangan dihitung dengan 4 rasio keuangan yang memperoleh hasil sebesar 138,33\%. Pada perspektif pelanggan diperoleh hasil sebesar16,41\%. Pada perspektif bisnis internal diperoleh hasil sebesar 18,1\%. Dan pada perspektif pertumbuhan dan pembelajaran diperoleh hasil sebesar $18,63 \%$. Berdasarkan hasil yang telah dianalisis, dapat disimpulkan bahwa kondisi Koperasi Kartika Sultan Ageng Tirtayasa masuk dalam kategori "Sangat Baik".
\end{abstract}

\section{Kata Kunci Balanced Scorecard, Penilaian Kinerja.}

\section{PENDAHULUAN}

Perekonomian Indonesia memiliki tiga sektor kekuatan untuk melaksanakan kegiatan dalam tatanan kehidupan perekonomian, yaitu sektor negara, sektor swasta, dan sektor koperasi. Salah satu alternatif yang dapat ditempuh adalah melalui wadah koperasi serta melibatkan sistem kerjasama dengan berbagai pelaku usaha nasional. Koperasi merupakan salah satu pelaku ekonomi yang bersifat kerakyatan, sehingga koperasi dipandang cocok untuk perekonomian Indonesia. Koperasi diarahkan agar dapat berkembang sebagai badan usaha yang sehat sekaligus sebagai gerakan ekonomi rakyat. Dalam rangka mengetahui bagaimana pertumbuhan kinerja koperasi, maka dari pihak Kementerian Koperasi dan UKM selalu meninjau dengan cara mengadakan penilaian 
kesehatan koperasi. Kesehatan koperasi di sini dimaksudkan untuk mengetahui kondisi atau keadaan koperasi yang dinyatakan sehat, cukup sehat, kurang sehat, dan tidak sehat secara keseluruhan.

Koperasi Kartika Sultan Ageng Tirtayasa adalah koperasi yang merupakan organisasi non struktural di lingkungan TNI - AD berbadan hukum 5148/BH/PAD/518-Bid.kop/X/2014 merupakan koperasi yang didirikan khususnya untuk anggota TNI dan PNS kodim 0602 Serang, di mana koperasi ini merupakan sebagai wadah yang melakukan tugas pokok memajukan kesejahteraan anggota dengan mendukung kebutuhan pokok anggota beserta keluarganya. Koperasi Kartika Sultan Ageng Tirtayasa memiliki beberapa usaha, yaitu simpan pinjam dan pertokoan dengan sistem termin tunai maupun kredit.

Tabel 1. Data Perbandingan dan Partisipasi Anggota

\begin{tabular}{|l|c|c|c|c|}
\hline \multirow{2}{*}{\multicolumn{1}{c|}{ Jenis }} & \multicolumn{4}{c|}{ Tahun } \\
\cline { 2 - 5 } & $\mathbf{2 0 1 6}$ & $\mathbf{2 0 1 7}$ & $\mathbf{2 0 1 8}$ & $\mathbf{2 0 1 9}$ \\
\hline Anggota & 389 & 397 & 437 & 468 \\
\hline Patisipasi Anggota & 260 & 216 & 296 & 390 \\
\hline
\end{tabular}

Jika dilihat pada tabel tersebut, jumlah keanggotan pada Koperasi Kartika Sultang Ageng Tirtyasa selalu mengalami kenaikan yang signifikan, namun jika dibandingkan dengan jumlah anggota, keaktifan partisipasi anggota masih terdapat selisih yang cukup jauh. Hal ini dapat mengancam kelangsungan kemajuan koperasi, karena jumlah anggota koperasi saja tidak dapat menentukan tingkat keberhasilan dari suatu koperasi.

Dengan adanya partisipasi aktif dari setiap anggota dan juga kualitas dari pengurus koperasi tersebut, maka peran koperasi akan terwujud. Selain dilihat dari aspek keanggotaan, peningkatan kualitas pada koperasi juga tak lepas dari pemberdayaan aspek keuangan pada koperasi tersebut. Suatu koperasi dituntut harus mampu tetap bertahan guna membiayai seluruh kegiatan operasionalnya dan mengoptimalkan keuntungan dan mensinergikan seluruh sumber daya alam yang dimiliki.

Tabel 2. Jumlah Pendapatan Jenis Usaha

\begin{tabular}{|l|c|r|c|c|}
\hline \multirow{2}{*}{$\begin{array}{c}\text { Jenis } \\
\text { Pendapatan }\end{array}$} & \multicolumn{4}{|c|}{ Tahun } \\
\cline { 2 - 5 } & $\mathbf{2 0 1 6}$ & $\mathbf{2 0 1 7}$ & $\mathbf{2 0 1 8}$ & $\mathbf{2 0 1 9}$ \\
\hline Usipa & 1.251 .229 .001 & 1.411 .273 .210 & 1.675 .261 .781 & 2.001 .787 .200 \\
\hline Pertokoan & 1.057 .292 .252 & 978.215 .200 & 1.397 .226 .300 & 1.720 .562 .850 \\
\hline Jumlah & 2.308 .521 .253 & 2.389 .488 .410 & 3.072 .488 .081 & 3.722 .350 .050 \\
\hline
\end{tabular}

Berdasarkan observasi yang dilakukan, jika dilihat dari tabel di atas menunjukan adanya perkembangan yang baik untuk tiap tahunnya. Namun, jika dilihat antara usaha simpan pinjam dengan pertokoan tentu usaha simpan pinjam lebih tinggi dibanding dengan 
pertokoan. Selain itu, pendapatan atas pertokoan terdapat penurunan yang cukup tinggi antara tahun 2016 menuju tahun 2017 dan mulai mengalami kenaikan pada tahun 2018 hingga 2019. Meskipun mengalami fluktuasi, perkembangannya menunjukkan bahwa Koperasi Kartika Sultan Ageng Tirtayasa mengalami pertumbuhan dan perkembangan yang cukup baik, namun harus tetap memperhatikan beberapa hal yang dapat mempengaruhi jalannya usaha koperasi dan dapat berdampak lebih buruk.

Manajemen koperasi hendaknya juga melakukan pengukuran kinerja usaha yang dimiliki. Informasi mengenai kinerja akan memampukan manajemen koperasi untuk melakukan perbaikan, sehingga tujuan untuk meningkatkan kesejahteraan anggota dapat dicapai. Kemampuan mengukur kinerja akan memampukan manajemen koperasi untuk melakukan analisis lebih lanjut mengenai hal-hal yang menyebabkan adanya kinerja kurang baik, sehingga mampu memilih langkah-langkah penting untuk perbaikan. Pengukuran kinerja juga harus memperhatikan aspek lain dari segi non keuangan, sehingga akan menciptakan hasil yang baik dan seimbang. Oleh sebab itu, diperlukan pengukuran kinerja perusahaan menggunakan sistem pengukuran komprehensif, yang tidak terpaku pada ukuran hasil atau perspektif keuangan, namun mengukur pula kinerja non-keuangan yang dilakukan untuk menghasilkan kinerja keuangan tersebut, serta mampu menggambarkan kinerja perusahaan secara keseluruhan dan berimbang atau dikenal dengan metode balanced scorecard, karena setiap koperasi perlu dilakukan evaluasi keberhasilan untuk menilai kinerja dari koperasi tersebut.

Maka dari itu, berhasil tidaknya suatu koperasi tergantung dari segi peningkatan keuangan koperasi, kontribusi koperasi terhadap pembangunan, dan peran koperasi dalam mensejahterakan anggotanya serta kemampuan memperoleh barang dan jasa guna memenuhi kebutuhan anggotanya. Meskipun keberadaannya berpengaruh besar bagi kehidupan masyarakat, namun secara umum perkembangan koperasi di Indonesia saat ini kurang mendapatkan perhatian, karena koperasi kurang memperlihatkan kinerja dan citra yang lebih baik di masa sebelumnya.

\section{LANDASAN TEORI}

\section{Balanced Scorecard}

Istilah Balanced Scorecard yang dijelaskan oleh Mulyadi terdiri dari kata balance (seimbang) dan scorecard (kartu skor). Kata balance diartikan sebagai kinerja yang diukur secara berimbang dari sisi keuangan dan non-keuangan, mencakup jangka pendek dan jangka panjang, serta melibatkan bagian internal dan eksternal perusahaan. Sedangkan kata scorecard adalah kartu yang digunakan untuk mencatat skor hasil kinerja (Septiasari, Darmawan, \& Suarthana, 2015).

Mulyadi dalam bukunya Sistem Perencanaan Dan Pengendalian Manajemen bahwa Balanced Scorecard merupakan contemporary management tool (alat manajemen kontemporer) yang digunakan untuk meningkatkan kemampuan organisasi dalam melipatgandakan kinerja keuangan (Solichah, Dzulkirom, \& Saifi, 2015). Oleh karena itu, Mulyadi dan Setiawan dalam Sistem Perencanaan dan Pengendalian Manajemen menganggap bahwa penggunaan BSC dalam organisasi menjanjikan peningkatan signifikan kemampuan organisasi dalam menciptakan kekayaan (Herawati, Isnandi, \& Sari, 2018). 
Menurut Kaplan \& Norton, empat perspektif balanced scorecard terdiri atas perspektif keuangan, perspektif proses bisnis internal, perspektif pembelajaran dan pertumbuhan dan perspektif pelanggan (Sari \& Arwinda, 2015). Adapun jenisnya sebagai berikut:

A. Perspektif Keuangan

Dari perspektif keuangan ini, kinerja keuangan tetap digunakan dalam mengukur apakah dalam strategi organisasi, implmentasi strategi hingga pelaksanaan akan membawa dampak positif bagi organisasi. Pada perspektif ini, tujuan dan ukuran keuangan harus dapat berperan ganda, sehingga pada akhirnya dapat menentukan strategi, sasaran akhir dari sebuah tujuan yang telah disusun.

B. Perspektif Pelanggan

Perspektif pelanggan memungkinkan organisasi melakukan identifikasi dan pengukuran proporsi nilai yang akan diberikan organisasi kepada pelanggan dan pasar sasaran.

C. Perspektif Bisnis Internal

Pada perspektif proses bisnis internal dibutuhkan perhitungan dengan cara Network Growth Ratio (NGR) yang akan melakukan perbandingan atas jaringan pada unit kerja dengan perbandingan peningkatan jaringan unit. Adapun rumusnya sebagai berikut:

$$
\mathrm{NGR}=\frac{\text { Unit Kerja aktif }}{\text { Total Unit Kerja }}
$$

Dengan rasio ini, dapat diketahui tingkat kebutuhan produk barang dan jasa apakah sudah memenuhi kebutuhan anggota. Semakin tinggi nilainya, maka akan diketahui bahwa peningkatan jaringan dalam unit kerja semakin baik.

D. Perspektif Pembelajaran dan Pertumbuhan

Faktor-faktor yang harus diperhatikan pada perspektif pertumbuhan dan pembelajaran, yaitu:

1) Tingkat Kepuasan dan produktivitas kerja karyawan

$$
\mathrm{TPP}=\frac{\text { (Pendapatan bersih }: \text { jumlah pekerja) }}{\text { Pendapatan bersih }} \times 100 \%
$$

2) Tingkat persentase pelatihan karyawan

$$
\text { Pekerja Terampil }=\frac{\text { Pekerja yang diberikan pelatihan }}{\text { Total Pekerja }} \times 100 \%
$$

\section{Penilaian Kinerja}

Hasibuan dalam buku Manajemen Sumber Daya Manusia mendefinisikan penilaian kinerja adalah menilai rasio hasil kerja nyata dengan standar kualitas maupun kuantitas yang dihasilkan setiap karyawan (Pantalisa, Rantelangi, \& Kumawardani, 2015).

Anwar Prabu Mangkunegara juga dalam bukunya Manajemen Sumber Daya ManusiaPerusahaan mendefinisikan penilaian kinerja karyawan adalah suatu proses penilaian prestasi kerja pegawai yang dilakukan pemimpin perusahan secara sistematik berdasarkan pekerjaan yang ditugaskan kepadanya (Pantalisa, Rantelangi, \& Kumawardani, 2015). 
Penilaian Kinerja bagi individu berperan sebagai umpan balik tentang berbagai hal seperti kemampuan, keletihan, kekurangan dan potensinya yang ada pada gilirannya bermanfaat untuk menentukan tujuan, jalur, rencana, dan pengembangan karirnya. Sedangkan bagi organisasi merupakan hal yang penting kaitannya dengan pengambilan keputusan tentang berbagai hal seperti identifikasi kebutuhan program pendidikan dan pelatihan, rekrutmen, seleksi, program pengenalan, penempatan, promosi, sistem balas jasa, serta berbagai aspek lainnya dalam proses manajemen (Siagian, 2008).

\section{METODOLOGI PENELITIAN}

\section{Metode Prosedur Dan Penelitian}

Metode analisis data yang digunakan dalam penelitian ini, yaitu pendekatan deskriptif kualitatif menggunakan Balanced Scorecard untuk mengukur kinerja Koperasi Kartika Sultan Ageng Tirtayasa. Langkah-langkah yang dilakukan dalam analisis data, yaitu penjabaran visi, misi, strategi dan tujuan perusahaan ke dalam empat perspektif Balanced Scorecard, yaitu: perspektif keuangan, pelanggan, proses bisnis internal, pembelajaran dan pertumbuhan dalam bentuk sasaran strategik, ukuran hasil, dan ukuran pemacu kinerja. Langkah selanjutnya, yaitu pembobotan setiap perspektif, sasaran strategis, dan ukuran hasil. Kemudian mengukur kinerja masing-masing perspektif Balanced Scorecard. Langkah terakhir dalam pengukuran kinerja ini, yaitu menjumlahkan total skor BSC, kemudian menentukan apakah kinerja koperasi berdasarkan Balanced Scorecard sudah baik atau belum.

\section{Sumber Data}

Sumber data dalam penelitian ini disesuaikan dengan jenis data yang dikumpulkan. Oleh karena itu, berdasarkan hal tersebut, sumber data dalam penelitian ini adalah:

a. Sumber Data Primer

Pengambilan data dalam penelitian ini melalui pembagian kuisioner. Metode kuesioner atau angket digunakan untuk mengambil data mengenai perspektif kedua, yaitu perspektif anggota yang akan menilai citra koperasi dan kualitas pelayanan terhadap kepuasan anggota.

b. Sumber Data Sekunder

Sumber data sekunder dalam penelitian ini adalah :

1) Buku-buku yang relevan dengan judul penelitian.

2) Dokumen-dokumen resmi secara tertulis tentang kondisi objektif di Koperasi Kartika Sultan Ageng Tirtayasa yang memiliki relevansi dengan fokus masalah penelitian.

\section{Teknik Dan Prosedur Pengumpulan Data}

Teknik yang digunakan dalam penelitian ini (Bungin, 2011), yaitu:

a. Observasi

b. Kuisioner (angket)

Sampel yang akan diambil berdasarkan pada populasi anggota Koperasi Kartika Sultan Ageng Tirtayasa, yaitu sebanyak 469 orang. Penentuan sampel menggunakan rumus slovin dari suatu populasi, adapun rumusnya, sebagai berikut: 


$$
\mathrm{n}=\frac{\mathrm{N}}{1+\mathrm{Ne}^{2}}
$$

Dengan tingkat toleransi kesalahan adalah $10 \%$ atau 0,1 .

c. Wawancara

d. Studi Dokumentasi

\section{Prosedur Analisis Data}

Analisis data dalam penelitian dilakukan pada saat pengumpulan data berlangsung dan setelah selesai pengumpulan data dalam periode tertentu. Pada saat wawancara, sebenarnya sudah melakukan analisis terhadap jawaban yang diwawancarai. Bila jawaban yang diwawancarai setelah dianalisis terasa belum memuaskan, maka akan melanjutkan pertanyaan lagi, sampai tahap tertentu, diperoleh data yang dianggap kredibel. Aktivitas dalam analisis data (Miles \& Huberman, 2009), yaitu:

1) Data Reduction (Reduksi data) merupakan proses berfikir sintesif yang memerlukan kecerdasan dan keluasan dan kedalaman wawasan yang tinggi. Sedangkan mereduksi data berarti merangkum, memilih hal-hal yang pokok, memfokuskan pada hal-hal yang pentingdicari.

2) Data Display (penyajian data), penyajian data dapat dilakukan dalam uraian singkat, bagan, hubungan antar kategori dan sejenisnya. Penyajian data yang dilakukan, yaitu data-data yang diperoleh dari Koperasi Kartika Sultan Ageng Tirtayasa.

3) Conclusion drawing/verification merupakan kesimpulan awal yang dikemukakan masih bersifat sementara dan akan berubah bila ditemukan buktibukti yang kuat yang mendukung pada tahap pengumpulan data berikutnya.

\section{HASIL PENELITIAN}

Temuan penelitian ini adalah merupakan bagaimana menilai secara keseluruhan yang ada dan berkaitan dengan koperasi mulai dari kemampuan pengurus dalam mengelola keuangan, pelayanan dan kepuasan anggota, kemampuan untuk ketersediaan barang, serta kemampuan informasi dan komunikasi yang diberikan karyawan dengan menggunakan metode Balanced Scorecard atau BSC. Pada penelitian ini akan dijelaskan dengan menggunakan 4 perpektif berdasarkan teori BSC, sebagai berikut :

\section{Perspektif Keuangan}

a. Rasio Likuiditas

Rasio lancar/Current Ratio

Current ratio $=\frac{\text { aktiva lancar }}{\text { Hutang lancar }} \times 100 \%$

Current ratio $=\frac{\text { Rp. } 4.296 .516 .351}{\text { Rp. 977.297.823 }} \times 100 \%$

Current ratio $=439,6 \%$

Rasio likuiditas yang dihitung dengan perhitungan rasio lancar atau current ratio diperoleh sebesar 439, 6\%.

b. Rasio Solvabilitas

Debt to equity ratio 
Debt To Equity Ratio $=\frac{\text { Total hutang }}{\text { Total modal }} \times 100 \%$

Debt To Equity Ratio $=\frac{\text { Rp. } 986.052 .823}{\text { Rp. 3.287.606.073 }} \times 100 \%$

Debt To Equity Ratio $=29,9 \%$

Rasio solvabilitas yang dihitung dengan perhitungan rasio hutang terhadap total modal atau debt to equity ratio diperoleh sebesar $29,99 \%$.

c. Rasio Profitabilitas

Return On Asset

Return On Asset $=\frac{\text { Laba bersih }}{\text { Total asset }}$

Return On Asset $=\frac{R p . \quad 206.241 .863}{\text { Rp. } 4.479 .900 .759} \times 100 \%$

Return On Asset $=4,60 \%$

Rasio Profitabilitas yang dihitung dengan perhitungan rasio pengembalian asset atau Return on asset yang diperoleh koperasi Kartika Sultan Ageng Tirtayasa sebesar $4,60 \%$.

d. Rasio Aktivitas

Perputaran Piutang $=\frac{\text { Penjualan bersih }}{\text { piutang dagang }}$

Perputaran Piutang $=\frac{\text { Rp. 543.507.809 }}{\text { Rp. } 28.500 .000}$

Perputaran Piutang $=19,07$

Rasio aktivitas yang dihitung dengan perhitungan rasio perputaran piutang diperoleh sebesar 19,07

\section{Perspektif Pelanggan}

Pada perpektif ini dilakukan survei yang menggunakan kuisioner sebagai alat bantu pengumpulan data. Survey tersebut bertujuan untuk mengetahui kepuasan para anggota terhadap pelayanan yang diberikan oleh koperasi. Survey tersebut disebar pada beberapa responden yang merupakan anggota koperasi, Adapun pengambilan sampel nya menggunakan rumus slovin, sebagai berikut:

$$
\begin{aligned}
& \mathrm{n}=\frac{\mathrm{N}}{1+\mathrm{Ne}^{2}} \\
& \mathrm{n}=\frac{469}{1+469(0,1)^{2}} \\
& \mathrm{n}=\frac{469}{5,69} \\
& \mathrm{n}=82,42
\end{aligned}
$$

Responden yang menjawab kuisioner pada perspektif pelanggan sebanyak 82 orang dengan total pertanyaan sebanyak 10 pertanyaan untuk tiap-tiap responden, di mana pertanyaan poin 1 dan 2 mengenai identitas diri.

Selanjutnya pada pertanyaan tiga sebanyak $31,7 \%$ responden menjawab sangat puas, selanjutnya sebanyak $54,9 \%$ menjawab puas dan sebanyak $13,4 \%$ menjawab cukup puas. 


\section{Penjelasan informasi yang diberikan oleh Pengurus yang berhubungan seputar Koperas} 82 tanggapan

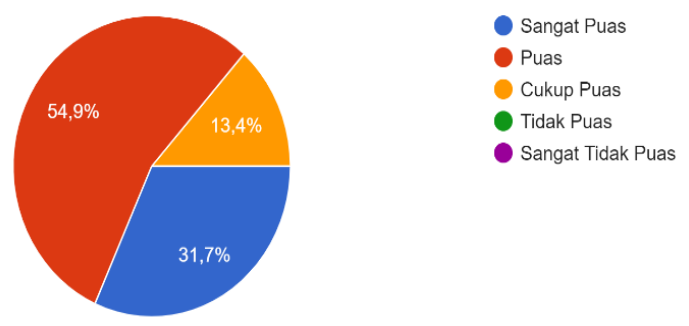

\section{Gambar 1. Hasil Kuesioner Mengenai Penjelasan Informasi Yang Diberikan Oleh Pengurus Yang Berhubungan Seputar Koperasi}

Pada pertanyaan empat hasil terbanyak yang diperoleh dari responden sebanyak $50 \%$ menjawab sangat puas dan disusul dengan selisih yang sangat tipis sebanyak $50 \%$ menjawab Puas. Hal ini dibuktikan dengan bertambahnya anggota yang bertransaksi di koperasi tiap tahunnya.

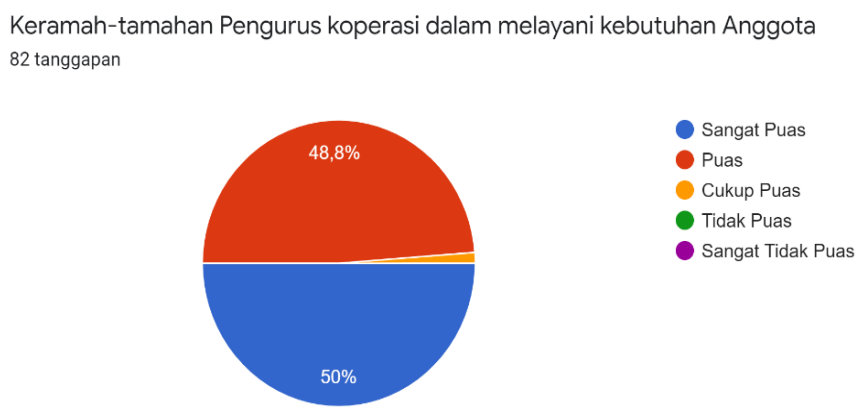

\section{Gambar 2. Hasil Kuesioner Mengenai Keramah-tamahan Pengurus koperasi dalam melayani kebutuhan Anggota}

Pertanyaan Lima perolehan hasil terbanyak yang dijawab oleh responden sebanyak $69,5 \%$ menjawab puas. Hal ini dibuktikan dengan beberapa fasilitas yang ada seperti tersedianya wifi, kamar mandi dan ruang tunggu dan kantin.

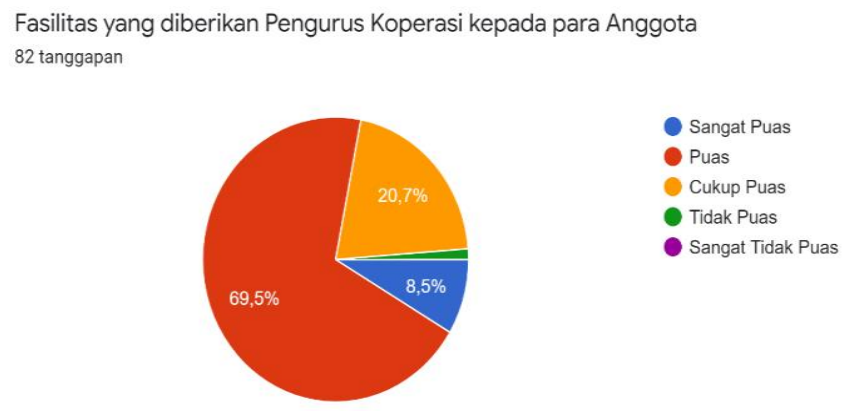

Gambar 3. Hasil Kuesioner Mengenai Fasilitas yang diberikan Pengurus Koperasi kepada para Anggota 
Pertanyaan Enam sebanyak 53,7\% responden menjawab sangat puas. Hal ini dibuktikan dengan adanya kenaikan jumlah hutang usipa anggota dari tahun ke tahun. Pada tahun 2018 diperoleh sebanyak Rp. 1.551.633.200,- dan ditahun 2019 diperoleh sebanyak Rp. 1.775.537.300,-

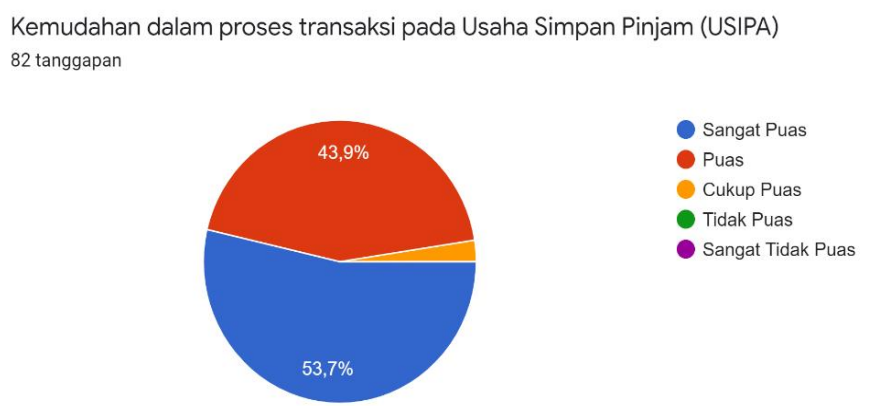

\section{Gambar 4. Hasil Kuesioner Mengenai Kemudahan dalam proses transaksi pada Usipa (Usaha Simpan Pinjam)}

Pertanyaan tujuh sebanyak 50\% responden menjawab sangat puas dan disusul dengan selisih yang tipis untuk responden yang menjawab puas sebanyak 46,3\%. Hal ini dibuktikan dengan meningkatnya jumlah mitra bisnis pada koperasi demi terpenuhinya semua kebutuhan anggota koperasi Kartika Sultan Ageng Tirtayasa.

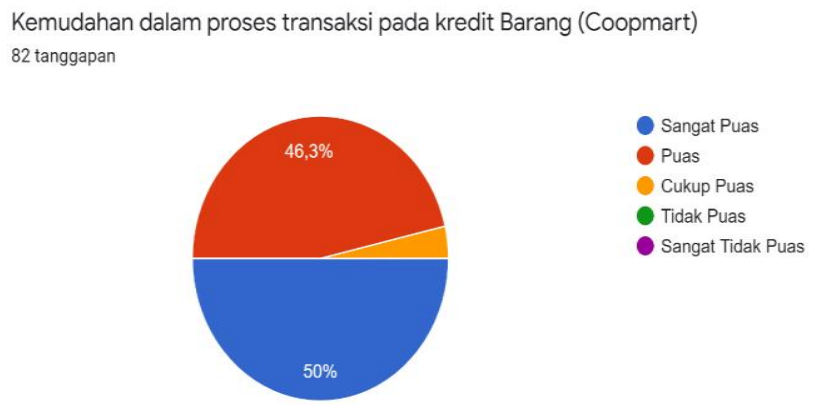

\section{Gambar 5. Hasil Kuesioner Mengenai Kemudahan dalam proses transaksi pada kredit Barang (Coopmart)}

Pertanyaan delapan sebanyak $67,1 \%$ menjawab puas. Namun hal tersebut masih menjadi perolehan dengan penilaian yang baik jika dibandingkan dengan minimnya sumber daya manusia yang ada pada koperasi sehingga para pengurus cenderung merangkap pekerjaan sebagai pengurus koperasi Kartika Sultan Ageng Tirtayasa dan sebagai anggota TNI Kodim 0602/Serang. 
Kecepatan dalam proses pelayanan yang diberikan oleh Pengurus Koperasi 82 tanggapan

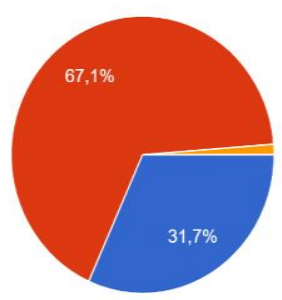

Gambar 6. Hasil Kuesioner Mengenai Kecepatan dalam proses pelayanan yang diberikan oleh Pengurus Koperasi

Pertanyaan Sembilan sebanyak 72,3\% menjawab puas. Sedangkan $22 \%$ responden menjawab sangat puas. Hal ini dibuktikan dengan minimnya keluhan atau komplain yang diajukan anggota pada koperasi Kartika Sultan Ageng Tirtayasa.

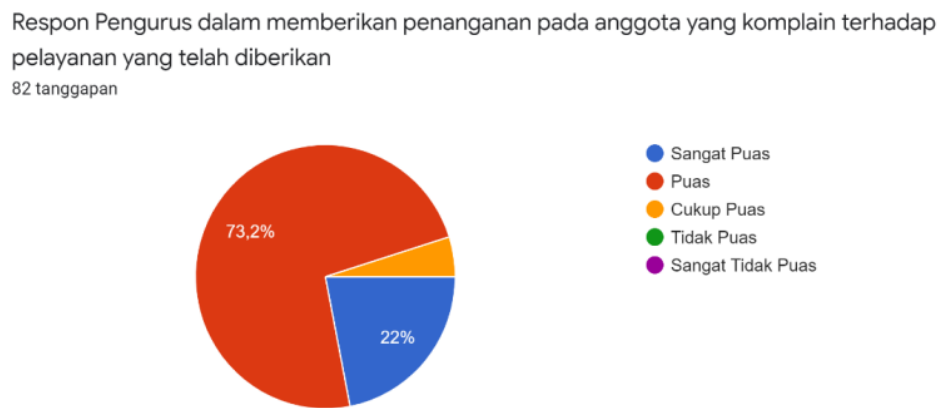

\section{Gambar 7. Hasil Kuesioner Mengenai Respon Pengurus dalam memberikan penanganan pada anggota yang komplain terhadap pelayanan yang telah diberikan}

Pertanyaan sepuluh sebanyak $74,4 \%$ responden menjawab puas. Hal tersebut dikarenakan para pengurus koperasi masih menggunakan sistem pencatatan, perhitungan serta prosedur yang bersifat manual, namun para anggota masih tetap merasa puas karena minimnya kesalahan selama para anggota bertransaksi dengan koperasi.

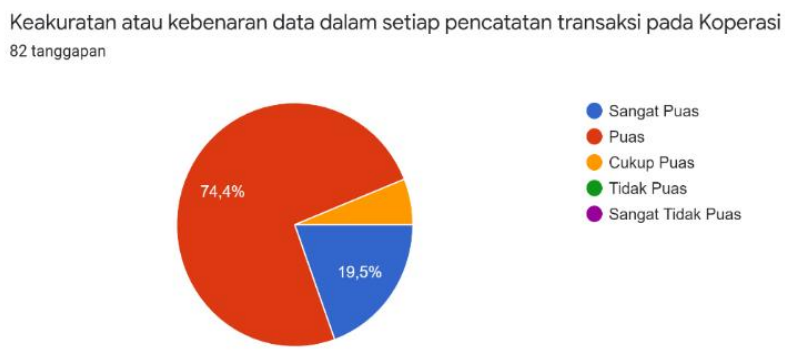

Gambar 8. Hasil Kuesioner Mengenai Keakuratan atau kebenaran data dalam setiap pencatatan transaksi pada Koperasi 


\section{Perspektif Proses Bisnis Internal}

Network Growth Ratio $=\frac{\text { Jumlah Unit aktif }}{\text { Total Unit mitra }}$

Network Growth Ratio $=\frac{39}{215}$

Network Growth Ratio $=0,18$ atau 18,1\%

Ratio NGR yang di peroleh pada perspektif proses bisnis internal pada koperasi Kartika Sultan Ageng Tirtayasa adalah sebesar 0,18 atau 18,1\%.

4. Perspektif Pembelajaran dan Pertumbuhan

a. Tingkat Produktivitas Pekerja

$$
\begin{aligned}
\mathrm{TPP} & =\frac{(\text { laba bersih }: \text { jumlah pekerja })}{\text { laba bersih }} \times 100 \% \\
\mathrm{TPP} & =\frac{(\text { Rp. } 206.241 .863: 10)}{\text { Rp. } 206.241 .863} \times 100 \% \\
\mathrm{TPP} & =\frac{\mathrm{Rp} .20 .624 .183,3}{\mathrm{Rp} .206 .241 .863} \times 100 \% \\
\mathrm{TPP} & =10 \% .
\end{aligned}
$$

Tingkat produktivitas pekerja yang didapat pada Koperasi Kartika Sultan Ageng Tirtayasa Sebesar 10\%.

b. Tingkat Presentase Pelatihan Pekerja

Pekerja Terampil $=\frac{\text { Pekerja yang diberikan pelatihan }}{\text { Total Pekerja }} \times 100 \%$

Pekerja Terampil $=\frac{3}{11} \times 100 \%$

Persentase Pekerja Terampil $=27,27 \%$.

Tingkat presentase pelatihan pekerja pada pekerja terampil diperoleh sebesar $27,27 \%$.

Hasil Indikator Kinerja Balanced Scorecard

\begin{tabular}{|l|l|c|c|c|c|c|}
\hline \multirow{2}{*}{ No } & \multirow{2}{*}{ Indikator Kinerja Utama } & \multicolumn{2}{|c|}{ Tahun } & \multirow{2}{*}{ Bobot } & \multirow{2}{*}{ Skor } & Kriteria \\
\cline { 2 - 3 } & Penilaian \\
\hline A. Perspektif Keuangan & $\mathbf{2 0 1 8}$ & $\mathbf{2 0 1 9}$ & & & \\
\hline 1 & Rasio Likuiditas & 534,4 & 439,6 & 10 & 487 & Sangat Baik \\
\hline 2 & Rasio Solvabilitas & 23,66 & 29,99 & 10 & 26,83 & Sangat Baik \\
\hline 3 & Rasio Profitabilitas & 5,55 & 4,6 & 10 & 5,08 & Cukup Baik \\
\hline 4 & Rasio Aktivitas & 49,77 & 19,07 & 10 & 34,42 & Sangat Baik \\
\hline B. Perspektif Pelanggan & 20 & 16,41 & Sangat Baik \\
\hline 1 & Survey Kepuasan Pelanggan \\
\hline C. Perspektif Proses Bisnis Internal & 20 & 18,1 & Sangat Baik \\
\hline 1 & Perkembangan mitra & 10 & 10 & Sangat Baik \\
\hline D. Perspektif Pembelajaran dan Pertumbuhan \\
\hline 1 & Produktivitas Pekerja & 10 & 27,27 & Sangat Baik \\
\hline 2 & Persentase Pelatihan Pekerja & 100 & 78,14 & A \\
\hline
\end{tabular}




\section{KESIMPULAN}

Berdasarkan data yang diperoleh dan hasil analisis yang telah dilakukan pada koperasi Kartika Sultan Ageng Tirtayasa menggunakan balanced scorecard untuk menilai kinerja dengan 4 metode penilaian yaitu perspektif keuangan, perspektif pelanggan, perspektif proses bisnis internal, dan perspektif pembelajaran dan pertumbuhan didapatkan perhitungan dengan perolehan rata-rata nilai sebesar 78,14 yang artinya Koperasi Kartika Sultan Ageng Tirtayasa masuk kategori dalam keadaan "Sangat Baik".

\section{DAFTAR PUSTAKA}

Bungin, B. (2011). Teknik Pengumpulan Data. In B. Bungin, Penelitian Kualitatif : Komunikasi, Ekonomi, Kebijakan Publik dan Ilmu Sosial (p. 111). Jakarta: Kencana.

Herawati, N. R., Isnandi, A. V., \& Sari, Y. E. (2018, April). Pengukuran Kinerja Koperasi Berbasis Balanced Scorecard. Jurnal Ekonika : Jurnal Ekonomi Universitas Kadiri, 3(1), 63-72.

Miles, M., \& Huberman, A. (2009). Analisis Data Kualitatif. Jakarta: Universitas Indonesia Press.

Pantalisa, K., Rantelangi, C., \& Kumawardani, A. (2015). Analisis Balanced Scorecard Sebagai Alat Pengukuran Kinerja Pada CV Yamaha Sinar Utama Hidayatullah Samarinda. Akuntabel, $12(2), 87$.

Sari, M., \& Arwinda, T. (2015, Maret). Analisis Balanced Scorecard Sebagai Alat Pengukuran Kinerja Perusahaan PT. Jamsostek Cabang Belawan. Jurnal Riset Akuntansi Dan Bisnis, 15(1), 31.

Septiasari, M. I., Darmawan, D. P., \& Suarthana, I. W. (2015, Oktober). Balanced Scorecard sebagai Pengukuran Kinerja Koperasi Perikanan Segaraning Harum Kabupaten Badung. Jurnal Manajemen Agribisnis, 3(2), 112.

Siagian, S. (2008). Penilaian Kinerja. In S. Siagian, Manajemen Sumber Daya Manusia (pp. 223-224). Jakarta: Bumi Aksara.

Solichah, A. D., Dzulkirom, M., \& Saifi, M. (2015). Analisis Balanced Scorecard Sebagai Sarana Pengukuran Kinerja Perusahaan (Studi Kasus Pada Pabrik Gula Pesantren Baru Kediri). Jurnal Administrasi Bisnis, 27(2), 1. 
